\title{
economics-of-security.eu
}

Syed Mansoob Murshed and Sara Pavan

\section{Identity and Islamic Radicalization in Western Europe}

June 2009

Economics of Security Working Paper 14

This publication is an output of EUSECON, a research project supported by the European Commission's Seventh Framework Programme.

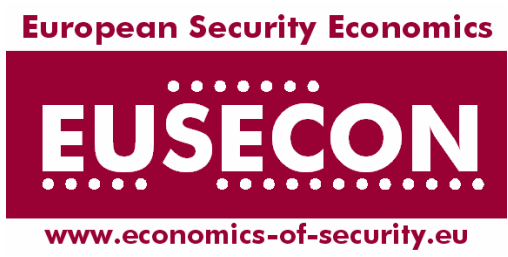

Economics of Security is an initiative managed by DIW Berlin 


\section{Economics of Security Working Paper Series}

The Economics of Security Working Paper Series combines outputs of European Security Economics (EUSECON), a research project supported by the European Commission's Seventh Framework Programme, with outputs of the Network for the Economic Analysis of Terrorism (NEAT), which is funded by the European Commission's Directorate General for Justice, Freedom, and Security. Papers not funded by EUSECON or by NEAT can still be submitted for inclusion in this Working Paper Series.

Correct citation: Murshed, S. M. and Pavan, S. (2009). "Identity and Islamic Radicalization in Western Europe". Economics of Security Working Paper 14, Berlin: Economics of Security.

First published in 2009

(C) Syed Mansoob Murshed and Sara Pavan 2009

ISSN: $1868-0488$

For further information, please contact:

Economics of Security, c/o Department of International Economics, German Institute for Economic Research (DIW Berlin), Mohrenstr. 58, 10117 Berlin, Germany.

Tel: $+49(0) 3089789-277$

Email: eusecon@diw.de

Website: www.economics-of-security.eu 


\title{
Identity and Islamic Radicalization in Western Europe
}

\author{
Syed Mansoob Murshed* \\ Institute of Social Studies (ISS) \\ PO Box 29776 \\ 2502 LT The Hague, The Netherlands \\ The Birmingham Business School \\ University of Birmingham \\ Edgbaston, Birmingham B15 2T'T, UK. \\ Centre for the Study of Civil War (CSCW) \\ PRIO, Oslo, Norway \\ Murshed@iss.nl \\ $\&$ \\ Sara Pavan \\ Institute of Social Studies (ISS) \\ PO Box 29776 \\ 2502 LT The Hague, The Netherlands \\ SaraPavan@yahoo.com \\ $29^{\text {th }}$ May 2009
}

\begin{abstract}
This paper argues that both socio-economic disadvantage and political factors, such as the West's foreign policy with regard to the Muslim world, along with historical grievances, play a part in the development of Islamic radicalized collective action in Western Europe. We emphasise the role of group identity based individual behaviour in organising collective action within radicalized Muslim groups. Inasmuch as culture plays any role at all in radicalization, it is because individuals feel an imperative to act on the basis of their Muslim identity, something to which different individuals will attach varying degrees of salience, depending on how they place their Muslim identity based actions in the scheme of their multiple identities. We also emphasize the role of the opportunistic politician, from the majority European community, in fomenting hatred for Muslims, which also produces a backlash from radicalized political Islam. We present comparative evidence on socio-economic, political and cultural disadvantage faced by Muslim minorities in five West European countries: Germany, the UK, France, Spain and the Netherlands.
\end{abstract}

Keywords: Identity, Radicalization, Clash of civilizations, Terrorism.

\footnotetext{
* Financial support from the European Union funded MICROCON and EUSECON projects are acknowledged.
} 


\section{$1 \quad$ Introduction}

During the past decade Western European countries have become increasingly fearful of the phenomenon of "home-grown terrorism" arising out of the radicalization of youthful first, second and even third generation Muslim immigrants. According to recent estimates, Muslims number 15-17 million in the EU-27 (Vaisse 2008). Radicalized individuals, born and bred in the West were involved in major terrorist attacks carried out in Europe since 9/11, such as the Madrid train bombings of March 2004, the London bombings of July 2005, as well as the 30 major failed plots discovered in the continent in the five years following 9/11 (Benjamin in Perry and Negrin 2008: 92). The media and the political debate point the finger of culpability to a particular religionIslam-as the source of this violent mobilisation. In addition to these acts of violence, Islamic "radicalization" also finds its expression in non-violent acts of defiance and statements of difference, such as the wearing of the bijab or head scarf and other distinct cultural practices. These symbolic actions produce discomfiture among the majority West European citizenry, as these are also seen as aggressive rejections of Western civilization.

Additionally, these developments help explain the rise in popularity of theories of civilizational clashes between the West and Islam (Huntington, 1996; Lewis, 2003). Furthermore, a heated debate over the possibility of harmonious integration of Muslim communities has emerged. Countries with a traditional multi-cultural approach, such as the Netherlands, have experienced the emergence of a "Dutch-Muslim cultural war" (Scroggins 2005 in Verkuyten and Yildiz 2007). In the UK, the activities of the Commission on Integration and Cohesion have marked a shift from multiculturalism and celebration of differences towards integration (Briggs and Birdwell 2009). Right-wing 
parties capitalizing on anti-Muslim antipathy have gained popularity throughout Europe, and the Muslim population of the continent have become the principal source of public anxieties (Modood 2003).

Although there is a vast body of work on how Islamic radicalization functions, and an even larger literature on the dangers it poses, the development of radicalization is often assumed to have emerged in a socio-economic and political vacuum. Implicit in these analyses is the attribution of violence to the innate nature of (a monolithic) Islamic mindset. The hatred for the West by some Muslim groups is treated as a given; hence conflict with the West necessarily follows. Some Western writers, such as Lewis (2003), also depict Muslims as wallowing in wounded pride about their historical decline, which fills some among them with a virulent hatred for the West. Huntington (1996) states that: "the underlying problem for the West is not Islamic fundamentalism. It is Islam, a different civilisation, whose people are convinced of the superiority of their culture and are obsessed with the inferiority of their power" (Huntington 1996: 217).

The problem with these 'culturalist' views is that it treats global religons, such as Islam, as monolithic, whereas in reality there are many faces of Islam across both historical time and at the present. Secondly, and more importantly, individual identity is regarded as a singular phenomenon, ignoring the multiplicity of identities that individuals may possibly possess (Sen, 2008). Thus, it is conceivable for an individual to be simultaneously a Muslim, a European citizen, a believer in democracy, as well as someone who respects difference and human rights. Furthermore, culture is not immutable; rather it evolves over time, and changes as material conditions alter. For example, compared to a century ago, few today would regard Catholicism or Confucianism as intrinsically inimical to 
capitalist development. It is important to note, however, that individual identification with group grievances is central to collective action surrounding Muslim radicalization.

The alternative explanation for disgruntled Muslim behaviour in Europe lies in wider socio-economic disadvantage, the theoretical underpinnings for which date back to Ted Gurr's (1970) classic work on relative deprivation as the source of rebellion. Stewart (2008) has documented the systematic disadvantage that Muslim groups face in European countries and worldwide (Muslims are a fifth or more of humanity). These range from economic discrimination in terms of jobs and lower incomes to under representation in public life. This phenomenon may be described as the horizontal inequalities that Muslims suffer from in contemporary Europe. Horizontal inequality is group-based inequality, rather than the inequality in an otherwise culturally or ethnically homogenous society; see Stewart (2000) on this. Muslim citizens in Europe are systematically poorer, suffer from greater unemployment and are less than proportionately represented in public life (Stewart, 2008), in addition to the opprobrium their cultural identity attracts. In short, Muslims in Western Europe may be subject to an inequality of opportunity on account of their identity; something that produces systematic disadvantage in the sense of Roemer (1998).

This paper will argue that both socio-economic disadvantage and political factors, such as the West's foreign policy with regard to the Muslim world, along with certain historical grievances play a part in the development of radicalization. Inasmuch as culture plays any role at all in radicalization, it is because individuals feel an imperative to act on the basis of their Muslim identity, something to which different individuals will attach varying degrees of salience, depending on how they place their Muslim identity based actions along the schema of their multiple identities. Muslim disadvantage is attributable both to 
the socio-economic deprivation faced by Muslim migrants in Europe, and the plight of the global Ummah (Muslim world), where the perceived Western policies towards this predicament (in Palestine, Iraq, Afghanistan and so on) are crucial. We also highlight the role of the opportunistic politician from the majority (white) community in fomenting hatred for Muslims, which also produces a backlash from radicalized political Islam. All over Western Europe there has been a growth in single issue, anti-immigrant, especially anti-Muslim immigrant parties in Denmark, the Netherlands and elsewhere. Racist messages that breed fear of minorities like Muslims can emanate from attention seeking politicians, who campaign on a single issue that scapegoat a particular group for all of society's ills (crime, unemployment and so on). Some citizens among the non-Muslim majority are more susceptible to this message, particularly if they are less educated, more economically vulnerable and being disadvantaged themselves may have negative experiences of close interaction with Muslim migrants.

The rest of the paper is organised as follows: section 2 contains a brief sketch of ideas underpinning fundamentalism and violence in Islam; section 3 presents a selected review of the literature concerned with the formation of individual identity, and the collective action that emanates from it, in accounting for home-grown radicalization in Europe; section 4 is concerned with political economy on how fear (of Muslims) and hatred (for the West by certain Muslim groups) may interact; section 5 focuses on five Western European countries (Germany, the UK, France, Spain and the Netherlands) and presents evidence on socio-economic, political and cultural disadvantage suffered by Muslim minorities; finally section 6 is by way of conclusion.

\section{The Anatomy of Muslim Radicalization}


A monolithic religious identity may have been misleadingly overemphasized in attempting to explain radicalization. American scholars such as Samuel Huntington and Bernard Lewis have engaged in 'culture talk', postulating the incompatibility of Islam with Western values: "turn[ing] religion into a political category" (Mamdani 2004: 24). A reference to Muslim people as a homogenous set of people, inherently prone to radicalization due to their religious beliefs, becomes the basis of cultural explanations for the rise of Islamic radicalization. As argued above, culture needs to be nuanced, the manner in which it evolves in response to material progress (or the lack of it) needs to be taken into account, as well as the fact that individual human beings have multiple cultural identities (Sen, 2008).

Contemporary racism in Europe is driven more by disdain for cultural identities such as Islam, rather than biologically based phenomenon, such as complexion, as was the case until the recent past. This explains the rise in anti-Muslim sentiment, which is not merely an indignant reaction to violence perpetrated by Muslims, but is symptomatic of a wider disdain for Muslim culture. There are differences across various European nations. In some European nations it may be less politically incorrect to openly cast unqualified aspersions on Muslims and Islam. ${ }^{1}$ According to surveys ${ }^{2}$, negative perceptions about Muslims among non-Muslims have grown: in 2008 52\% in Spain ${ }^{3}, 50 \%$ in Germany, $38 \%$ in France and 23\% in the UK felt negative about Muslims, considering them a threat to Western civilization. The same survey indicates growth in the Muslim sense of identity amongst Muslims immigrants in Europe.

\footnotetext{
${ }^{1}$ In the UK, for example, the anti-Muslim Dutch politician Geert Wilders was prevented from showing his anti-Islam film, Fitna, in the British House of Lords in February 2009 on the grounds that it might incite racial hatred; by contrast, his popularity is said to be on the rise in his native Netherlands.

2 http:/ / pewglobal.org/reports/display.php?ReportID=262

3 In Spain, for example, a liberal online newspaper recently accused Prime Minister Zapatero of being willing to turn Spaniards into Muslims for his alleged policy of appeasement towards Muslim communities in the country; see http://www.espana-liberal.com/20060929-zapatero-nos-volvera-musulmanes.html.
} 
It is widely believed that Islam is an intolerant and violent religion, with its sacred texts replete with inflammatory statements about its foes. Increasingly, even in liberal circles, Islam is thought of, and depicted, as a religion that endorses violence against its 'enemies'. Unfortunately, these notions are based on selective and limited interpretation. It is, therefore, appropriate to cite some of its scripture that endorse tolerance, as these are less well known in liberal circles. Religious scripture is, by definition, open to myriad varieties of interpretation. Despite this, it can be argued that the Islam acknowledges and celebrates racial diversity, ${ }^{4}$ and requires believers to accept other religions as an article of faith. ${ }^{5}$ Some of the sayings of the Prophet Muhammad and his cousin and son-in-law Ali, during Islam's first century (the $7^{\text {th }}$ century AD) are testimony towards inclusiveness. ${ }^{6}$ These statements illustrate how acts of gratuitous violence towards non-Muslims would be unjustifiable to believing Muslims in the absence of genuine grievances. The important point is that a devout Muslim must eschew racism in all forms, should not hate Judeo-Christian civilization and reject universal values of toleration; rather the dislike of the West emanates from injustices perpetrated thereof. Moreover, historically, Muslim countries and empires have exercised greater toleration towards other religions,

4 "---We have created you male and female, and have made you nations and tribes that ye may know one another--the noblest of you, in the sight of Allah, is the best in conduct". Quran: 049.013. "And of His signs is the creation of the heavens and the earth, and the difference of your languages and colours". Quran: 030.022. English translations from Marmaduke Pickthall's, The Glorious Quran, http://www.islam101.com/quran/QTP/index.htm

5 "Say (O Muhammad): We believe in Allah and that which is revealed unto us and that which was revealed unto Abraham and Ishmael and Isaac and Jacob and the tribes, and that which was vouchsafed unto Moses and Jesus and the prophets from their Lord. We make no distinction between any of them, and unto Him we have surrendered”. Quran: 003.084

${ }^{6}$ Consider an excerpt from Muhammad's Last Sermon (circa 632 AD): “An Arab has no superiority over a non-Arab nor a non-Arab has any superiority over an Arab; also a black person has no superiority over a white person, nor a white person has any superiority over a black person, except by piety and good action. Indeed the best among you is the one with the best character......

http://www.themodernreligion.com/prophet/prophet lastsermon.htm

Ali, the 4th Islamic Caliph, also the cousin and son-in-law of Muhammad in a letter to Malik-e-Ashtar, his governor designate to Egypt (circa 656-661 AD): "Remember, Malik, that amongst your subjects there are two kinds of people: those who have the same religion as you have; they are brothers to you, and those who have religions other than that of yours, they are human beings like you.---- Let your mercy and compassion come to their rescue and help in the same way and to the same extent that you expect Allah to show mercy and forgiveness to you." (Nahjul Balagha)

http://www.al-islam.org/nahjul/letters/letter53.htm\#letter53. 
compared to European practice until the $19^{\text {th }}$ century (a good example would be Muslim ruled Medieval Spain).

Historical acts that may add to the sense of Muslim collective grievances include events such as the wholesale expulsion of Muslims who did not convert to Christianity from Spain (in the $16^{\text {th }}$ and $17^{\text {th }}$ centuries) and Sicily ( $14^{\text {th }}$ century). During the $20^{\text {th }}$ century in the Middle East, the British-French Sykes-Picot pact (during the First World War) resulted in an extremely unfair disposition of the former Ottoman territories. Later, the emergence of what many regard as a colonial settler state, Israel, and the West's lack of even handed behaviour towards the protagonists in the Arab-Israeli conflict spawned deep resentment. Other areas of Muslim disadvantage in the recent past include Kashmir in India, and Bosnia in the European Balkans. Their predicament is often blamed on Western double standards towards the plight of Muslims.

Terrorism is only part of the total set of actions adopted by radicalized Muslim groups in Europe, as many adopt strategies of peaceful protest, and some simply reject certain Western cultural practices. Terrorism was defined as "propaganda by the deed" (Mikhail Bakunin) ${ }^{7}$; a violent means of attracting attention to a political objective, which may or may not have a religious basis. The focus of the bulk of the recent literature on radical Islam in the West is on "home-grown terrorism", which is conducted by individuals who "were born and/or spent most of their lives in the West; were radicalised within their Western home countries; have trained and achieved attack-capability in their Western home countries" . Note that, suicide bombing or attacks is not exclusively a Muslim

\footnotetext{
${ }^{7}$ In a letter to a Frenchman on the Present Crisis (1870), http://www.anarchyisorder.org/CD\%234/TXTversions /Bakoenin, $\% 20$ Michael $\% 20-\% 20$ Letters $\% 20$ to $\% 20 \mathrm{a} \% 20$ frenchman.txt

${ }^{8}$ Sam Mullins, http://www.terrorismanalysts.com/pt/index.php?option=com_rokzine\&view=article\&id=12, accessed May $7^{\text {th }} 2009$.
} 
phenomenon; data from the Chicago Project on Suicide Terrorism shows that the principal user and inventor of suicide attacks are the LTTE in Sri Lanka, a rather secular and definitely not Islamic group; see Pape (2006).

Having noted that terrorism is not the only means of confronting the West, we could argue that the Muslim religious discourse that accompanies the retreat into confrontational behaviour towards the majority communities in their countries of birth can be linked to the spread of the Salafiyya movement (which means following those who went before, in this case early Muslims) among Muslim diasporas (ICG 2005). Such dynamics should be analysed against the backdrop of the current three-fold manifestation of Islamic activism: political, missionary and jihadi (ICG 2005). Reportedly, "political Islamists make an issue of Muslim misgovernment and social injustice and give priority to political reform to be achieved by political action; missionary Islamists make an issue of the corruption of Islamic values and the weakening of faith and give priority to a form of moral and spiritual rearmament that champions individual virtue as the condition of good government as well as collective salvation. Jihadi Islamists make an issue of the oppressive weight of non-Muslim political and military power in the Islamic world and give priority to armed resistance" (ICG 2005: ii). Political Islam, as embodied by the Muslim Brotherhood political parties and their affiliates in Muslim majority countries, does not put forward a violent strategy of action: it is usually organized in the forms of political parties and it seeks power through political rather than violent means. These parties rarely get anything approaching a majority of votes in democratic Muslim majority nations; see Islam (2005). Missionary activism tends to refrain from political confrontation; rather it tends to concentrate on preaching and reviving the community of believers (Ummah). It includes the Tablihgi (evangelical) and the Sufi (mystical) movements, which are theologically quite distinct from each other, but 
avowedly peaceful. Jihadi Islamists are instead committed to violence with a view to defending (or expanding) Dar-al-Islam (the world of Islam). Originally comprised of the Jihadi Salafiyya, who had abandoned preaching activism and turned to radicalisation, as well as the Qutbists (inspired by the radical Egyptian thinker Sayyid Qutub), it has gradually seen the merging of the two currents and their fusion with Bin Laden's alQaida network, with its chief ideologue Al-Zawahiri, who was the former leader of the Egyptian Qutbist movement. European Salafism itself has bifurcated into a reformist current and a Jihadi current; the latter has allegedly been infiltrated by Bin Laden's AlQaida network. There is a duality in European Salafism: on the one hand it provides a means for the personal search for religious truth; on the other hand it connects: "all individuals of the Diaspora to a wider community - the Ummah or community of believers- as the primary locus of Muslim political obligation” (Escobar Jose, 2006).

\section{Identity and Collective Action}

With regard to identity based collective action, it is convenient to begin with the political economy of altruism. This occurs when the donor derives utility or happiness from the utility of the recipient. Altruistic sensibilities also apply to those who espouse a cause, such as the well-being of the Muslim Ummah. Essentially, there are two forms of altruism. One is referred to as pure altruism. This is when the donor derives utility from the benefit of the recipient or the furtherance of a cause, but can obtain that utility passively because it does not necessarily require him to participate actively or directly. He is happy that a purpose is served, even when persons other than himself do the good deed. For example, individuals can be in favour of animal welfare, without actually paying into or participating in animal charities. They are happy that others do so. In this case, altruism is a public good, and as is well known there can be free riding on the public 
good (this is when we let others pay for the common good). Another form of altruism is known as impact philanthropy, see Duncan (2003): this when the individual not only cares about someone else, but also feels compelled to actually participate in other people's welfare or act in support of a just cause. This situation can lead to oversubscription, for example when the coffers of charities swelled with funds following the Tsunami of December 2004.

Secondly, we have the innovative approach to the economics of identity, as proposed by Akerlof and Kranton (2000). Their approach provides another view on why identities can become salient, and how the collective action problem, as described by Olson (1965), is resolved. Individuals derive utility not just from consumption or identification with a cause, but also from their own behaviour that is in conformity to their sense of identity and the like minded behaviour of other members of the group they belong to; for example the performance of prayers by the individual and his co-religionists. Here the position that the group occupies in societal hierarchy is also crucial to their collective self-esteem. All of these factors (utility from identity based actions, similar actions by other group members, and the position of their group) enter an explicit utility function. The individual not only derives utility from a vector of his own actions, but also similar actions of other like-minded individuals belonging to his group, and above all his own identity or self image, which in turn depends on the group's social standing. The last factor depends both on the group's economic disadvantage, and other factors such as the West's foreign policy towards the Muslim world. It can be argued, however, that low social standing may encourage individuals to abandon their primary identity in favour of other, less frowned upon, identities. These actions, however, would be insincere and based on strategic considerations. Also, following Akerlof and Kranton (2000), it is possible to show that many such individuals may be deterred from this course of action 
by their peers. If another group member suffers disutility from other-identity based behaviour by another group member, they may lure the errant individual back to the fold, provided that the cost of doing so to themselves is not too large and is less than the loss inflicted on the deviant group member. This is more likely amongst poor but culturally homogenous communities suffering from widespread unemployment, and who live proximately to each other in isolated ghettos with close kinship ties (as in many metropolitan locations throughout Europe where Muslim families related to each other live cheek by jowl). Moreover, the dissident group may use this type of cooperative behaviour to solve the collective action problem, as described by Olson (1965). Thus, group grievances become individual grievances, and individuals act upon their group grievances. It is not their own poverty that will necessarily drive individual membership of a radical group, but the disadvantage faced by the group at large. But most importantly, if theory of politicized collective identity explains the behaviour of ordinary group members, the economics of identity sheds light on the kind of intra-group dynamics which lead to increasingly widespread radicalized collective action.

Other disciplines in the social sciences (outside economics and political economy) have a longer history of emphasising the identification with a collective meaning of one-self. Mirroring Akerlof and Kranton's importance of identity is the much earlier thought of Johan Galtung. He hypothesized that "aggression is most likely to arise in social positions of rank disequilibrium. In a system of individuals, it may take the form of a crime, in a system of groups the form of revolutions" (Galtung 1964:98). Simon and Klandermaans (2001) synthesized different branches of sociological and social psychological theory on inter-group confrontation and identified three subsequent steps for the formation of politicised collective identities: "a form of collective identity that underlies group members' explicit motivations to engage in $[\ldots]$ a power struggle" 
(Simon and Klandermaans 2001: 323). Identity raises the awareness of shared grievances, the emergence of adversarial attributions to blame opponents and the involvement of society by triangulation. The concept of collective identity helps explain the increased tendency towards Islamic radicalization in Western European countries, and particularly among the youths born and raised in such countries. Religion, being "among the most important markers of group identity" (Verkuyten and Yildiz 2007: 1449), might become a strategic tool for uncertainty reduction, as well as self-enhancement. Particularly in countries where policies towards migrants put an emphasis on assimilation, those belonging to ethnic minorities may turn to their in-groups as a source of identification, and as a means of reducing uncertainty (Verkuyten and Yildiz 2007). Further, ethnic groups who are discriminated against may resort to group-based strategies involving "increased in-group identification and a distancing from the majority group" (Verkuyten, Yildiz 2007: 1449) for their own self-enhancement.

What is the role of economic deprivation in the process of collective identity positioning? There are three related concepts that can be applied here: relative deprivation, polarization and horizontal inequality; see Murshed and Tadjoeddin (2009) on this. The notion of relative deprivation dates back to the work of Ted Gurr (1970) who defines it as the discrepancy between what people think they deserve, and what they actually think they can get, or in short the disparity between aspirations and achievements. Polarisation is defined to occur when two groups exhibit great inter-group heterogeneity combined with intra-group homogeneity. The notion of horizontal or inequalities between groups, classified by ethnicity, religion, linguistic differences and so on is thought to be an important cause of contemporary civil war and sectarian strife. The expression 'horizontal inequality' originates in the work of Frances Stewart; see Stewart (2000), and should be distinguished from vertical inequality, which is the inequality within an 
otherwise homogenous population. Stewart (2008) demonstrates Muslim horizontal inequalities in Europe, which serves to fuel the fire of radicalization.

That said, from the viewpoint of the individual perpetrator of radicalized Islamic activities, intrinsic motivation, which is often the outcome of their collective sense of humiliation, plays a major role; therefore deterrence against these groups may backfire if it hardens their resolve to resist, as is modelled by Addison and Murshed (2005). Also, perpetrators of extreme acts of violence are not always uneducated and poor, as is the case in the Middle East (Krueger and Maleckova, 2002), or even with the London bombers or the murderer of Theo van Gogh in the Netherlands. In fact, education can act as an indicator of reliability. Individual utility functions associated with terrorism or radical acts are altruistic and based on the social positioning of the group and not the individual; these individuals are motivated by the plight of their impoverished and oppressed brethren. There is not only identification with a cause, something that can also be present in passively interested individuals, but an imperative to participate in furthering that cause. Participatory altruism or identity based behaviour leads to a stronger urge to act compared to ordinary altruism, where the individual can passively derive utility from the furtherance of the cause he espouses. This drive to take direct action may result in violence, including self-destruction. From the viewpoint of individual choice, extreme acts like suicide bombing may be rational, as explained by Wintrobe (2002). This is because the individual has made an all or nothing choice between solidarity with a cause and individual autonomy. In this situation, increasing deterrence has little impact on individual choice, which is another way of saying that deterring radicalization will not succeed in preventing people from committing themselves to their cause, even if the success rate of individual acts of radicalization diminishes. 
Just as aggrieved Muslims, indoctrinated and herded by conflict entrepreneurs into groups for collective action, may feel a profound hatred for the West, certain politicians and political parties in the West seek their own political self-advancement by preaching the dangers posed by Islam in general, and Muslim migrants in particular. In 2001, for instance, the Danish People's Party campaigned with a poster showing a young blond girl and the statement "When she retires, we will be a Muslim majority nation": the party later came in third in terms of seats in Parliament, experiencing a 70\% increase in its vote bank. In the 2002 French Presidential elections, Jean-Marie Le Pen of the Front National - later convicted for spreading Islamophobic messages in an interview to the Newspaper Le Monde in 2003- won a place in the runoff against Chirac and received 17\% of votes. In August 2007, the Governor of Carinthia in Austria, Joerg Haider promised to ban the construction of mosques and minarets in his Province; the Austrian right won 28\% of votes in the September 2008 general elections. This is the notion of fear of a minority, which in part is whipped up by exaggerated statements from hate-mongering politicians (Glaeser, 2005) and the political "exploitation" of it. The appeal of anti-Muslim political parties, such as the British National Party or the Dutch Lijst Pim Fortuyn, has pushed governing parties to adopt non-accommodating policies towards immigrants, albeit moderate versions of those proposed by right-wing extremists, in an effort to maximise their constituencies (Fetser and Soper, 2003).

Following Glaeser (2005) we can think of the hate message against Muslim migrants as originating in a signal sent out by a politician, whose word (credibility) is not exactly the 'coin of the realm', because he may be deliberately sending out a false hate message as a cheap way of advancing his own popularity. Its attractiveness to the public will depend 
on their need for scapegoats and their own personal life experiences of these minority groups. Not all these signals will be believed: for example, some hate mongering politicians may be mistrusted, the better educated among the public may discount part of the message and others with greater knowledge of the minorities based upon personal interaction may similarly disregard this signal. ${ }^{9}$ There is a cost to members of the public of verifying the veracity of the signal through a search process. Among the majority group there will be two different types of citizens. One group, the high cost type of individual, suffers both a greater perceived loss from Muslim dissidents and has a higher cost of verification of the signal. This is all the more so, if the search costs of verifying the signal entail an earlier lumpy fixed cost in education, say. These individuals are more likely to abandon the search for truth in favour of the hate message. Not only that, but they will clamour for public action against the object of their phobia. Also, after major riots involving (male) Muslim youths and terrorist attacks like the London bombings, all individuals from the majority community may believe the hate message for a time, effectively tarring all Muslims with the same (terrorist) brush. If enough voters believe the signal then public action will be called for, and Islamophobia or fear of Muslims acquires the nature of a public good. Note that because of the non-rivalled and nonexcludable nature of a public good, even those who do not derive utility from these actions are 'forced' to 'consume' the good and finance it via taxation. The state will be compelled to act at the taxpayers expense. These take the form of anti-Muslim and antiimmigrant legislation making it difficult for families to join relatives in Europe, integrationist nationalisation policies such as linguistic and cultural proficiency tests, the banning of head-scarves and veils (niqab or burqa). These policies are more likely to bear fruition in European nations where proportional representation is the rule, and coalition

\footnotetext{
${ }^{9}$ The PEW world surveys indicate that dislike of Muslims in Europe is greater among the older and less educated segments of the population; http://pewglobal.org/reports/display.php?ReportID=262.
} 
governments the norm, as minor anti-Muslim parties can influence public policy, unlike in the UK, where despite some anti-Muslim rhetoric, the Islamophobic agenda is prevented from surfacing by the leadership of the leading parties in a winner take all (first past the post) electoral system that does not favour a minority-single issue political platform, even if anti-terrorist laws and measures have become more rigorous.

The model in Murshed (2008) interacts the fear (a public good) outlined above with hatred for the West amongst some radical Muslim groups in the West (a club good in the sense that only voluntary membership and contribution allows individuals to participate in the collective action). The results are unsurprising, both a rise in Muslim economic and political deprivation as well as anti-Muslim policies at home and abroad raise confrontation between radical Muslim groups and the state. The important point, once again, is that radicalization does not develop in a vacuum: it is fuelled by Western fear (and the intrinsic dislike) of Islam and Muslims. This fear is not just confined to potential violence emanating from Muslim Jihadi extremists, it also includes a general dislike for non-violent Muslim conventions and civilization.

\section{$5 \quad$ Evidence from Western European countries}

We now present evidence regarding socio-economic, political and cultural collective disadvantage suffered by Muslims in five European countries where Islamic radicalization has fuelled significant political debate.

\section{FRANCE}


France is currently the European country with the largest Muslim community. Estimates point to a Muslim population of around 6 million people, i.e. $10 \%$ of the population (Franz 2007). Two million of them are French citizens ${ }^{10}$. The discovery that the French national Zacarias Moussaoui was involved in the planning of $9 / 11$, and the bouts of urban rioting in the autumn of 2005, when mostly youth of North-African origin set the French banlieues on fire ${ }^{11}$, has paralleled the increase in support expressed for the rightwing and anti-immigrants party Front National, led by Jean-Marie Le Pen, who obtained $11 \%$ of the votes in the 2007 presidential election ${ }^{12}$.

A number of second- and third generation migrants, who were born and brought up in the country, have self-reportedly developed resentment towards mainstream French society. The perception of constituting a second class citizenry and discrimination experienced from "housing to entry into nightclubs" (Franz 2007: 102) has led "many in this group [not to] think it possible to consider oneself both Muslim and French" (Franz 2007:100). A greater interest in religion within Muslims has emerged. A study conducted among suspected members of Al-Qaida in French prisons found that while they generally did not come from devout families, they later turned to Islam as a source of selfidentification and self-respect, previously denied them by French society: "to become someone who is feared, if not respected, one has to be openly Muslim. Islam liberates. In this sense, I feel very Muslim” (Rosenthal in Perry and Negrin EDS 2008: 188). Moreover, a 2001 poll published by the French newspaper Le Monde found for example that Muslims were attending mosque and praying more frequently than they had been in 1994, when a similar survey was conducted ${ }^{13}$.

\footnotetext{
${ }^{10}$ http://www.meforum.org/337/islam-in-france-the-french-way-of-life-is-in, accessed May $8^{\text {th }} 2009$. ${ }^{11} \mathrm{http}: / /$ www.timesonline.co.uk/tol/comment/columnists/minette_marrin/article589708.ece, accessed May $8^{\text {th }} 2009$.

12 http://news.bbc.co.uk/2/hi/europe/6582479.stm, accessed May $10^{\text {th }} 2009$.

13 http://pewforum.org/publications/reports/muslims-europe-2005.pdf, accessed May 10 2009.
} 
French Muslims suffer from socio-economic, political and cultural group inequalities. The percentage of Muslims who do not finish secondary school appears considerably higher than that of non-Muslims (Stewart 2008). The Paris-based Montaigne Institute has found that the unemployment rate for North Africans at 30\% is considerably in excess of the national average. ${ }^{14}$ The chances of finding employment in the service sector are rather thin: discrimination is particularly widespread in the retail and hospitality industries, which involve contact with people (Franz 2007: 102). It is estimated that $60 \%$ of inmates in French prisons are Muslim (Vidino in Perry and Negrin EDS 2008). Residential discrimination is also high, with most of the Muslim population concentrated in low-income housing around the major cities, the banlieus. Such areas host the "longterm jobless men and women of Arab descent and more recent immigrants" (Franz 2007: 102). The government's definition of districts such as Paris's Clichy sous-Bois as "sensitive urban areas" has aroused much political debate.

\section{GERMANY}

Germany has a Muslim community amounting to around 3.2-3.4 million, which corresponds to $4 \%$ of a total population of 82.4 million (ICG 2007). The country hosts the biggest Turkish diaspora community in Europe. Evidence has been collected that "the attacks of 9/11 were partially planned in Hamburg, Germany, where three of the four pilots of the hijacked planes had lived and met, and from where they received extensive financial and logistical support until the day of the attack" (Vidino in Perry and Negrin EDS 2008: 158). In 2006 a plot to blow up trains in Dortmund and Koblenz

\footnotetext{
${ }^{14}$ http://pewforum.org/publications/reports/muslims-europe-2005.pdf, accessed May $10^{\text {th }} 2009$.
} 
failed; in September 2007, German authorities charged a native German and youthful convert to Islam with heading a terrorist cell planning attacks against American targets in Germany. Moreover, the country has experienced an augmented interest in Islam within the Turkish community. This has manifested itself in the increase of the number of female students attending school wearing the hijab, and the reversion to traditional practices among the Turkish middle classes that has stirred the businesses related to traditional weddings and circumcisions in Berlin's districts of Kreuzberg and Neukolln (Franz 2007).

A number of right-wing politicians with an assimilative view on Muslim immigration demanded language courses and loyalty tests for the naturalization of Muslims "as proof of Germanness and democratic credentials" (ICG 2007: 3) have found support in the German population, 58\% of whom expect "a coming conflict with the Muslim population" (a two-fold increase since 2004), 46\% fear an imminent terrorist attack, and 42\% believe terrorists may be hidden among the Muslim population (ICG 2007: 22).

Horizontal inequalities are suffered by Muslims in the socio-economic as well as in the political realm. Prospects of higher educational access, which assists upward social mobility are particularly bleak for Turks. Educational success at the secondary level in Germany was more highly correlated with parental socio-economic status and educational success than in any other OECD country (ICG: 22). Turkish students in German universities are outnumbered by the Chinese ${ }^{15}$. Turkish immigrants are less likely to pursue apprenticeships that lead to jobs, and their rates of unemployment are high.

\footnotetext{
15 There are 25,000 Turkish University students, compared to a population of 235,989 Turkish 18 to 25 year olds. Chinese university students number 27,000, ICG: 2007.
} 
Although the German housing system is not comparable to the French in terms of ghettoization (housing companies must adopt distributional criteria when allocating dwellings to immigrants and ethnic minorities, and a threshold of no more than $20 \%$ of foreigners for each apartment complex was established by some companies), around $50 \%$ of Turks still report discrimination when looking for accommodation. (EUMC 2006).

After the new citizenship law was introduced in 2000, most parties are seeking to secure immigrant members (ICG report: 30). However, the legacy of the "imperial and state citizenship law", in force from 1913 to 1999, which deprived the migrant "guest workers" of political rights, though granting them access to welfare, has denied first and second-generation immigrants access to genuine political representation. Islamic activism has also been curtailed by the activities of the Verfassungsschutz, the provincial and national offices mandated to protect the constitution, "which monitor potentially antidemocratic or un-constitutional activities of both registered and underground civil society groups" (ICG report 2007: 3). Being labelled Islamist by these authorities can lead to the refusal of citizenship, access to public housing and even residence permits.

\section{UNITED KINGDOM}

The United Kingdom has a Muslim population of around 1.6 million, accounting for $2.8 \%$ of the national population, $46 \%$ of whom are British born, with a third aged below $15^{16}$. Serious anti-Muslim political rhetoric did not materialise in the UK after the London bombings of 2005 as: (a) Premier Tony Blair and other political figures diffused any anti-Muslim backlashes unlike many of their counterparts in Europe following

${ }^{16}$ http://pewforum.org/publications/reports/muslims-europe-2005.pdf, accessed May 8 $8^{\text {th }} 2009$. 
atrocities or plots in their countries, (b) Muslim leaders immediately condemned the attacks, and (c)in 2007 the Research Information and Communications Unit, operating within the newly formed Office for Security and Counter-Terrorism, advised Ministers to stop using the phrase "war on terror" and cease talking about the "Muslim problem" (Briggs and Birdwell 2009). Despite this, moves were made away from a traditionally multicultural approach to immigration to an assimilative policy, marked by the establishment of a Commission on Integration and Cohesion (Briggs and Birdwell 2009). In the wake of $9 / 11$, civics classics and a loyalty oath were added as requirements for citizenship. More recently, a coalition of both left and right has reportedly emerged which criticizes the UK government for what they call a policy of appeasement towards Islamic groups, such as the FOSIS (Federation of Student Islamic Societies) and the Leicester's Islamic Foundation (Briggs and Birdwell 2009).

British society is reportedly experiencing an identity crisis: a public-opinion poll taken shortly after September 11 found that $26 \%$ of the population felt that Islam was a threat to Western values (Travis in Fetser and Soper 2003). The 2009 Gallup Report on Coexistence (2009) shows that $26 \%$ of the British public think that people with different religious practices threaten their way of life. These figures are lower than in comparable Western European countries with substantial Muslim populations. Islam has indeed become a visible religion in the country: $80 \%$ of British Muslims state they attend the mosque regularly, and results of a survey conducted in London show that "there are now more people attending mosque regularly than going to church". ${ }^{17}$ Despite some evidence that British Muslims are generally better off than Muslims in other European Countries (Fetser and Soper in Pew 2006), there is evidence that they suffer from socio-economic, political and cultural group inequalities.

\footnotetext{
${ }^{17}$ http://pewforum.org/publications/reports/muslims-europe-2005.pdf, page 6.
} 
School attainment and achievements are systematically lower within the Muslim minority. Pakistani and Bangladeshi rates of attainment in language and literacy at an early age were $57 \%$ of those of whites (Stewart 2008); 36\% of British Muslims drop out of school with no qualifications; a fifth of 16 to 24 year old Muslims in Britain are unemployed (Franz 2007). Almost one-third of Muslims of working age have no qualifications, the highest proportion for any faith group (Bunglawala in Briggs and Birdwell 2009). Inequalities are also present in the access to jobs, and in employment conditions. In 2004 a British government report indicated that the unemployment rate among Muslim cohorts in the UK was three times that of the general population (Franz 2007); 14\% of Muslims over 25 are unemployed, compared with a national unemployment rate of 4\%. Residential segregation is also encountered: the London Pakistani community, comprised of around 140.000 people, is concentrated in four of London's districts. One of them, Newham, is the fourth worst place to live in the UK. ${ }^{18}$

Muslims are also under-represented in the political sphere: in 2005, less than $2.3 \%$ of members of parliament were from ethnic minority groups, which represent $10 \%$ of the population (Stewart 2008). The British police have, however, set a target of $25 \%$ ethnic minority staff by $2009^{19}$.

\section{SPAIN}

According to the U.S. Department of State International Religious Freedom Report of 2008, there are 1.15 million Muslims in Spain, two thirds of them being immigrants without

18 http://www.channel4.com/4homes/on-tv/best-and-worst/best-and-worst-places-to-live-2006-08-0618 p $1 . h$ tml

19 http://news.bbc.co.uk/1/hi/uk/4032987.stm 
Spanish nationality and the rest being converted Spaniards ${ }^{20}$. The presence of Islam in the country has reportedly grown exponentially since the 1970s, as the result of both the number of migrants from neighbouring Islamic counties, particularly Morocco, and the tendency among Spaniards to convert (Mehrotra 2005).

The train bombings in Madrid in 2004 reinforced the unrest with the Muslim minority that the Spanish general public had felt since the events of $9 / 11: 82 \%$ of those in the general public who see Islamic identity on the rise, call it a bad thing. ${ }^{21}$ Data collected by the Spanish Guardia Civil document that between January 2004 and March 2005 there were 30 reported anti-Muslims attacks in the country. ${ }^{22}$ In 2006 the newspaper El Pais reported that after March 11, the number of attacks conducted by right-wing youth groups against Mosques, and threatening letters sent to Imams had increased. ${ }^{23}$

Spanish Prime Minister Zapatero has adopted a tone and language respectful to Islam. After the Madrid attacks on March $22^{\text {nd }}$ 2004, he declared in a meeting with the representatives of the Arab League that the Spanish Muslims have demonstrated the incompatibility between Islam and Terrorism, ${ }^{24}$ and defined Islam as a pacific and tolerant source of identity. After a decade-long debate, in January 2005 the Spanish government permitted the teaching of Islamic subjects at public schools in major cities of Spain with a significant Muslim presence (Mehrotra 2005). However, despite some political commitment, the record of horizontal inequalities suffered by Muslims in Spain leaves much to be desired.

\footnotetext{
${ }^{20}$ See http://www.state.gov/g/drl/rls/irf/2008/108473.htm, accessed May 20 2009.

${ }^{21}$ Pew 2006, The Great Divide: How Westerners and Muslims view each other, http://pewglobal.org/reports/display.php?PageID=830, accessed May $10^{\text {th }} 2009$.

22 http://www.elmundo.es/elmundo/2007/02/14/espana/1171468241.html, accessed May 10 2009.

23 http://www.webislam.com/?idn=5476, accessed May $8^{\text {th }} 2009$.

24 http://www.webislam.com/pdf/pdf.asp?idn=549, accessed May $10^{\text {th }} 2009$.
} 
Although permitted by law, the building of mosques is frequently met with opposition from Spanish society. Spanish converts are still the only credited advocates for Muslim rights in the country (Mehrotra 2005).

A number of studies have documented the perception of discrimination: a field study in 2000 found that many Muslims in Spain complained of overt discrimination against their children by non-Muslim fellow pupils, who constantly stigmatised them as Moors. Another study conducted by Gema Martin-Munoz found that many Moroccan immigrants, despite being well-educated, still met with difficulties when looking for qualified jobs, as "many Spaniards did not want to be seen on the same footing as a Moor” (Mehrotra, 2005: 87).

Residential segregation results in the concentration of the Muslim population in the suburbs of Madrid, Barcelona and other Andalusian cities, which are characterised by a depressed socio-economic status. Since 2003 there have been nearly 6000 Moroccans and Algerians in Spanish jails, mostly serving sentences for petty crimes.

\section{NETHERLANDS}

According to the last official data released by the Central Bureau of Statistics, on January $1^{\text {st }} 2004$, the Muslim population in the Netherlands comprised about 1 million, accounting for $5.8 \%$ of the total population. Two thirds of them were originally from Turkey and Morocco, and 40\% of them were second generation migrants. Despite being a country with traditionally a multicultural approach towards migrants: "Dutch society and the majority group have become rejecting and assimilative in their orientation toward ethnic and cultural diversity" (Verkuyten and Yildiz 2007:1446). The assassination in 
2002 of Pim Fortuyn, a Dutch politician who had famously declared Islam a backward culture, as well as the murder in 2004 of Dutch film-maker Theo van Gogh by Mohammed Bouyeri, a young Dutch-Moroccan, heightened the simmering tension between the Dutch autochthon (native-white) population and the Muslim minority. In 2002, following the assassination of Pim Fortuyn his new and avowedly anti-Muslim party won $18 \%$ of the votes in the Dutch general elections ${ }^{25}$, securing 26 seats in the Parliament (Irwin and Van Holsteyn 2004). The murder of Theo van Gogh in 2004 was followed by unprecedented vitriolic (even crusade-like) anti-Islamic acts and statements that were not countered by the governing elite. After the assassination, the Dutch Monitoring Centre on Racism and Xenophobia recorded a total of 106 violent incidents against Muslim targets in just one month. In December 2004 a Muslim primary school in Uden was destroyed in an arson attack. $80 \%$ of the Dutch population was found to be in favour of "stricter measures to force integration" 26 , after commentators and officials had made it clear that Muslims should accept Holland's liberal views- "either voluntarily of by government coercion" 27 . As indicated, these developments were in sharp contrast to the reaction of the British leadership to the London bombings of 2005. The loyalty of Muslim Dutch politicians born in Muslim countries (Ahmed Abu Talib, Mayor of Rotterdam, for example) has been called into question. Survey results released in April 2009 show that $40 \%$ of the Dutch population agree with the anti-Muslim sentiments of right-wing politician Geert Wilders, although only $18 \%$ would vote for him. ${ }^{28}$

Muslims in the Netherlands suffer from different dimensions of horizontal inequality. As far as access to the labour market is concerned, it has been noted that more than half of

\footnotetext{
25 http://migration.ucdavis.edu/mn/more.php?id=2642 040 0, accessed May 22 2009.

${ }^{26} \mathrm{http://pewforum.org/publications/reports/muslims-europe-2005.pdf,} \mathrm{accessed} \mathrm{May} 8^{\text {th }} 2009$.

27 http://pewforum.org/publications/reports/muslims-europe-2005.pdf, accessed May $8^{\text {th }} 2009$.

${ }^{28}$ http://www.dutchnews.nl/news/archives/2009/04/wilders_ideas_enjoy_40_support.php, accessed May $11^{\text {th }} 2009$.
} 
the Turks and more than $60 \%$ of Moroccans have an unskilled job, compared with less than 30\% for the native Dutch (Stewart, 2008). An experiment was carried out in September 2005 where 150 CVs appropriately geared to job vacancies were sent to numerous companies in the Netherlands. Half carried a traditional Dutch name and the other half a foreign/Islamic-sounding name. Of the 75 "Dutch" CVs, 69 persons were invited for interview, and of the 75 "foreign" CVs only 33 persons were invited" (EUMC 2006).

With regard to education, $40 \%$ of Turks and $45 \%$ of Moroccans have had no more than primary education (Stewart 2008). Among second and third generation Muslim migrants drop-out rates from school are higher (Stewart, 2008); further, in mixed schools, the performances Muslim children also tend to be far below the level of Dutch-natives (Driessen and Merry, 2006).

Residential segregation is also widespread, when it comes to Muslim communities. To an extent, this may be an issue of concern for most ethnic minorities, who tend to concentrate in low cost housing areas, where criminality, poverty and pollution are significant (EUMC 2006). However, a recent survey shows that in the Netherlands $12.2 \%$ of respondents do not want to have Muslims as neighbours, as compared to only 5.17\% who do not want migrants as neighbours (Strabag and Listhaug 2008: 278). This also shows that Muslims are the most poorly regarded of all minorities.

In a survey of 104 Turkish-Dutch participants in the Utrecht area, Verkuyten and Yildiz (2007) found that more than 50\% indicated a low or neutral Dutch identification and $63.3 \%$ indicated neutral or high dis-identification (i.e. a reaction "against things Dutch and develop[ment of] a so-called reactive or oppositional identity" (Verkuyten and Yildiz 2007: 1450). 


\section{Conclusions}

Muslim terrorism and radicalization has been viewed either as a type of criminal deviant behaviour arising from low individual opportunity costs of abandoning the productive labour market, or alternatively ascribed to the civilizational clash that Muslims will inevitably initiate. Group identity and low self-esteem has, in this approach, been relatively neglected, and where present, the possible multiplicity of individual identity (Muslim and other) has been ignored.

The country-based evidence in this paper shows that the radicalization does not occur in a social, political and economic vacuum; nor does it lend support to the 'culture talk' hypothesis, which singles out radicalization - and terrorism- as an intrinsic characteristic of Islamic practice. We have argued that politicised collective identity can account for the conflictual interaction between "fear" and "hatred" which largely underpins the emergence of Islamic fundamentalism in Western Europe. "Fear" is the anxiety felt by the majority; it is both the cause and the effect of fear-creating messages publicised by attention-seeking politicians. In this respect, there are differences across countries, British politicians have commendably counteracted feelings of fear following atrocities perpetrated by Muslims; the same is true for the governing Spanish leadership, although it met with less success. In the rest of Western Europe the conventional political elite has been less than robust in coming forward to allay excessive fearfulness of Islam. By "hatred", we refer to a set of behaviour and actions adopted by Muslim migrants, ranging from non-violent acts such as the wearing of hijabs to outright terrorism, all of which are part of a common attempt to signal difference and defiance to the majority community. 
Horizontal inequalities suffered by Muslims, both worldwide and within Europe, are central to the formation of collective grievances. Perceptions regarding European foreign policies towards the Muslim world, which are ridden with double standards, are equally to blame. Majority versus minority inter-group conflict in Western European countries may also be regarded as a form of "positional" conflict, with two groups competing for material as well as symbolic resources. In this connection, a great deal of ink has been wasted in pointing out the relatively better social background of the perpetrators of violence, compared to the average position of the Muslim communities whose cause they espouse. The economics of identity and altruism, which we have sketched above, indicates that it is not an individual's poor personal circumstance that provides the spur towards direct action; rather it is the condition of the group. Akerlof and Kranton's (2000) approach provides further insights into intra-group dynamics, whereby leaders bent on confrontation have ways of preventing members from straying, something that is easier to monitor in poor and deprived communities.

Evidence from the country-based profiles further shows that discrimination against Muslims is rife, leading to conditions that are ripe for political mobilisation. Islamic leaders bent on confrontation are more able to produce adversarial attributions according to which "a specific out-group, an authority, or "the system", must be blamed for the group's predicament" (Simon and Klandermaans 2001: 325). In turn, this allows further politicisation, as group members can then identify an external opponent group as "them" for what they are doing to "us" (Simon and Klandermaans 2001). Finally, society is called upon to take sides either with one-group or with its opponent: in such context, rightwing politicians are able to harness their constituencies' fear of Muslims to increase their support. Our case studies illustrate that fear-mongering is greater in some European countries, and the UK is the most at variance with continental Europe in being less 
Islamophobic. Interestingly, terrorism in this context may become a vehicle in the power struggle to win the heart and minds of the general public; allegedly, terrorists "have even tried to provoke authorities (the police or the government) to engage in oppressive action or legislation, hoping that such oppression will generate anger and solidarity on the part of potential allies or the general public" (Simon and Klandermaans 2001: 329).

Against the backdrop of a politicised Muslim identity, and substantial horizontal inequalities suffered by Muslims, domestic 'integrationist' policies aimed at 'moderate Muslims' are unlikely curb radicalization- let alone fight terrorism. Rather, they may backfire. American style integrationist policies are gaining favour in Europe, but these are doomed to failure unless the objects of the integrationist policies are also offered equality of opportunity, which means redressing Muslim horizontal inequalities. Furthermore, and quite crucially, if individuals have multiple identities as we suggest, then they are more likely to act on the basis of their other (European and non-Muslim) identities when they are less socio-economically deprived and less frowned upon. Radicalization is also unlikely to diminish unless the existing horizontal inequalities are narrowed, and the cultural opprobrium towards Islam that stems from and reinforces disadvantage, continues to be fomented by attention-seeking politicians. The presence of virulent Islamophobic messages (more common in some European countries) not only instils fear, but also elicits hatred, and can undo the pacific-integrationist effects of material progress amongst Muslims residing in Europe.

\section{References}

Addison Tony and S. Mansoob Murshed (2005) 'Transnational Terrorism as a Spillover of Domestic Disputes in Other Countries', Defence and Peace Economics, 16 (2): 69-82.

Akerlof, George and Rachel E. Kranton (2000) 'Economics and Identity', Quarterly Journal of Economics, 115(3): 715-753. 
Briggs, R. and Jonathan Birdwell (2009) Radicalization among Muslims in the UK, Microcon Working Policy Working Paper http://www.microconflict.eu/projects/PWP7 RB JB.pdf.

Driessen, Geert and Michael S. Merry (2006) 'Islamic Schools in the Netherlands: Expansion or Marginalization?', Interchange 37 (3): 201-223.

Duncan, Brian (2003) 'A Theory of Impact Philanthropy", Journal of Public Economics, 88 (9-10): 2159-2180.

Escobar Stemman and Juan Jose (2006) 'Middle East Salafism's Influence and the Radicalization of Muslim Communities in Europe", The Middle East Review of International Affairs, 10(3), Article 1/10.

European Monitoring Centre on Racism and Xenophobia EUMC (2006), The Annual Report on the Situation regarding Racism and Xenophobia in the Member States of the EU. Vienna: EUMC.

Irwin Galen A. and Joop J.M. Van Holsteyn (2004), The 2002 and 2003 Parliamentary Elections in The Netherlands, Electoral Studies 23(3): 551-557.

Fetser, Joel S. and J. Christopher Soper (2003) 'The Roots of Public Attitudes toward State Accomodation of European Muslims' Religious Practices before and after September 11', Journal for the Scientific Study of Religion 42(2): 247-258.

Franz Barbara (2007) 'Europe's Muslim Youth: An Inquiry into the Politics of Discrimination, Relative Deprivation, and Identity Formation', Mediterranean Quarterly 18 (1): 89-112.

Gallup Foundation (2009) The Gallup Coexist Index 2009: A Global Study of Inter-faith Relations, Washington: Gallup.

Galtung, Johan (1964). 'An Editorial', Journal of Peace Research 1(1): 1-4.

Glaeser, Edward L (2005) 'The Political Economy of Hatred', Quarterly Journal of Economics, 120 (1):45-86.

Gurr, Ted Robert (1970) Why Men Rebel, Princeton: Princeton University Press.

Huntington, Samuel P (1996) The Clash of Civilizations and the Remaking of the World Order, New York: Simon and Schuster.

Krueger, Alan B and Jitka Maleckova (2002) 'Does Poverty Cause Terrorism', The New Republic, June 24: 27-33.

International Crisis Group (ICG) Report Middle East/North Africa (2005). 'Understanding Islamism', http://www.crisisgroup.org/library/documents/middle east north africa/egypt nor $\underline{\text { th africa } / 37 \text { understanding islamism.pdf. }}$

International Crisis Group (ICG) Report Europe 181 (2007). 'Islam and Identity in Germany', http://www.crisisgroup.org/library/documents/europe/181 islam in germany.pdf. 
Islam, Iyanatul (2005) 'The Political Economy of Islamophobia and the Global Discourse on Islam', Griffith University, Regional Outlook Paper No. 3.

Lewis, Bernard (2003) The Crisis of Islam: Holy War and Unholy Terror, London: Phoenix.

Mamdani, Mahmood 2004. Good Muslim, Bad Muslim. New York: Pantheon Books.

Mehrotra, Rajiv (2005) 'The Looming Shadow of the Crescent: Islam in Spain', Perspectives on Business and Economics 23(2005): 85-95.

Moodod, Tariq 2003. "Muslims and the Politics of Difference", The Political Quarterly 74(s1): 100-115.

Mullins, Sam 2007. Home-grown Terrorism: Issues and Implications. Perspectives on Terrorism 1(3).

http://www.terrorismanalysts.com/pt/index.php?option=com rokzine\&view=article\&i $\underline{\mathrm{d}=12}$ Accessed May $7^{\text {th }} 2009$.

Murshed, S Mansoob (2008) 'A Note on the Interaction between Identity Based Fear and Hatred', Peace Economics, Peace Science and Public Policy.

Murshed, S Mansoob and M Zulfan Tadjoeddin (2009) 'Revisiting the Greed and Grievance Explanations for Violent Conflict', Journal of International Development, 21 (1): 87-111.

Olson, Mancur (1965) The Logic of Collective Action, Cambridge MA: Harvard University Press.

Perry, Marvin and Howard E. Negrin EDS (2008) The Theory and Practice of Islamic Terrorism. New York: Palgrave Macmillan.

Pew Research Centre (2005) An Uncertain Road. Muslims and the Future of Europe.

Roemer, John E. (1998) Equality of Opportunity, Cambridge MA: Harvard University Press.

Sen, Amartya K (2008) 'Violence, Identity and Poverty', Journal of Peace Research, 45(1): 515.

Simon, B. and B. Klandermans (2001): Politicised Collective Identity: A Social Psychological Analysis, American Psychologist 56: 319-331.

Stewart, Frances (2000) 'Crisis Prevention: Tackling Horizontal Inequalities', Oxford Development Studies, 28(3): 245-62.

Stewart, Frances (2008) 'Global Aspects and Implications of Horizontal Inequalities (HIs): Inequalities Experienced by Muslims Worldwide', mimeo.

Strabac, Zan and Ola Listhaug (2008) 'Anti-Muslim prejudice in Europe: a Multi-level analysis of survey data from 30 countries', Social Science Research, 37(2008): 268-286. 
Vaisse, Justin (2008) 'Muslims in Europe: A Short Introduction', Brookings US-Europe Analysis Series

http://www.brookings.edu/ /media/Files/rc/papers/2008/09 europe muslims vaisse $\angle 09$ europe muslims vaisse.pdf, Accessed May $18^{\text {th }} 2009$.

Verkuyten, Maykel and Ali Aslan Yildiz (2007) 'National (Dis)identification and Ethnic and Religious Identity: A Study Among Turkish-Dutch Muslims', Personality and Social Psychology Bulletin, 33 (10): 1448-1462.

Wintrobe, Ronald (2002) 'Can Suicide Bombers Be Rational', Paper prepared for the DIW Workshop on Economic Consequences of Global Terrorism, www.diw.de. 